\title{
FIELD OBSERVATIONS OF THE 2015 (NOVEMBER 17, MW 6.4) LEFKAS (IONIAN SEA, WESTERN GREECE) EARTHQUAKE IMPACT ON NATURAL ENVIRONMENT AND BUILDING STOCK OF LEFKAS ISLAND
}

\author{
Lekkas E. ${ }^{1}$, Mavroulis S. ${ }^{1}$ and Alexoudi V. ${ }^{1}$ \\ ${ }^{I}$ National and Kapodistrian University of Athens, School of Sciences, Faculty of Geology and \\ Geoenvironment, Department of Dynamic Tectonic Applied Geology, Panepistimiopolis, 15784 \\ Athens,Greece,elekkas@uoa.gr, smavroulis@geol.uoa.gr,valexoudi@geol.uoa.gr
}

\begin{abstract}
On Tuesday, November 17, 2015 at 07:10:07 (UTC) a strong earthquake struck Lefkas Island (Ionian Sea, Western Greece) with magnitude Mw 6.4, depth of about 7 $\mathrm{km}$ and epicenter located $20 \mathrm{~km}$ southwest of Lefkas town. The seismic activity in the region was essentially expected after the 2003 Lefkas earthquake and the 2014 Cephalonia earthquakes. Between these earthquake affected areas, the tectonic stresses were not released after the 1948 Lefkas earthquakes. Instead, they were intensifying and accumulating until the generation of the 2015 event. It was felt in Lefkas and the surrounding region and caused the death of 2 people, the injury of 8 others, earthquake environmental effects (EEE) and damage to buildings and infrastructure. Secondary EEE were observed in western Lefkas and included ground cracks, slope movements and liquefaction. Primary effects were not detected in the field. Buildings damage were mainly observed in villages of Dragano-Athani graben in southwestern Lefkas. Among structures constructed with no seismic provisions, the stone masonry buildings and monumental structures suffered most damage, while the traditional buildings with dual structural system performed relatively well. Reinforced-concrete buildings were affected not so much by the earthquake itself but by the generation of secondary effects.
\end{abstract}

Keywords: Ionian Islands, strike-slip earthquake, active tectonics, earthquake environmental effects, earthquake-induced building damage.

\section{Пєрí $\lambda \psi \psi \eta$}

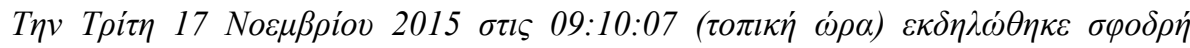

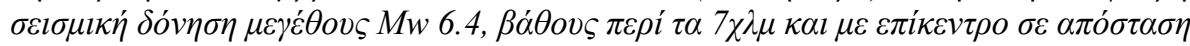

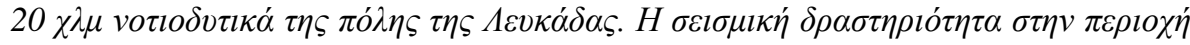

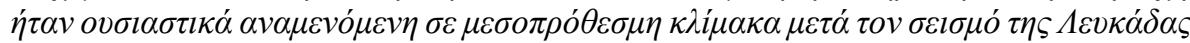

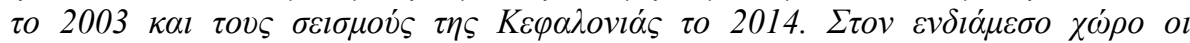

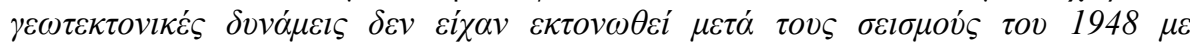

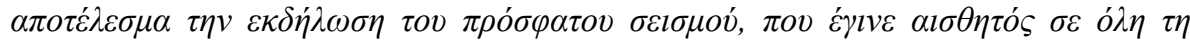

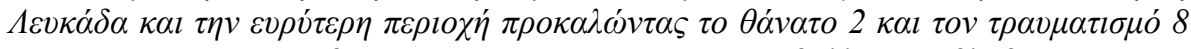

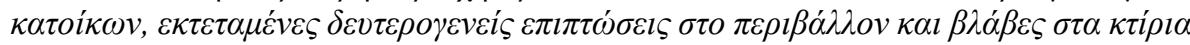

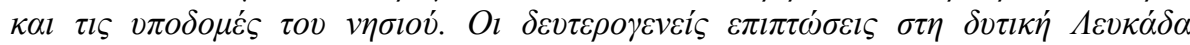

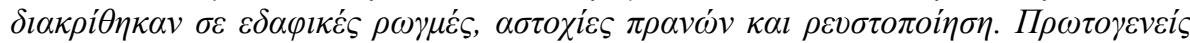

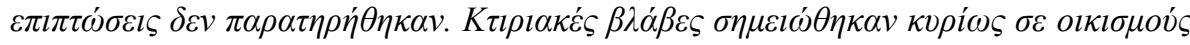




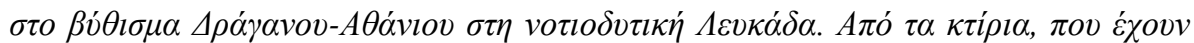

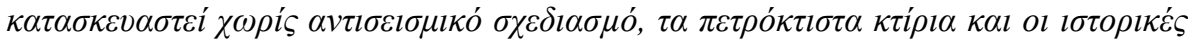

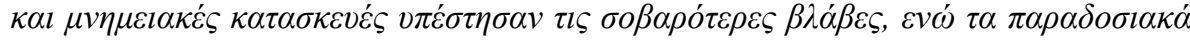

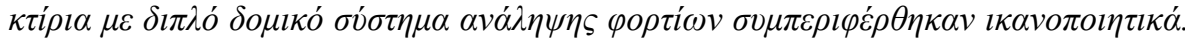

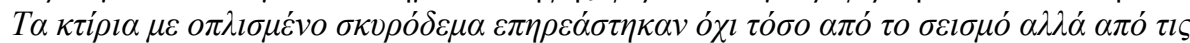

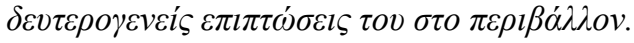

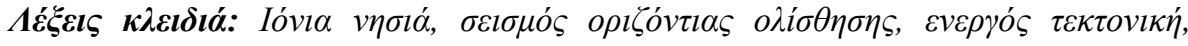

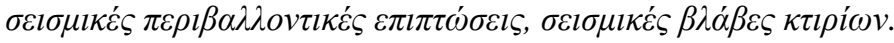

\section{Introduction}

In the morning of November 17, 2015 (07:10:14.6 UTC; 09:10 local time), an earthquake occurred in Lefkas Island (Ionian Sea, western Greece) (Fig. 1). It was assessed as Mw 6.4 (NOA, GFZ, UPSL, INGV) or Mw 6.5 (USGS, GCMT). It was felt predominantly on the western part of Lefkas and throughout the Ionian Islands, the western continental Greece and Peloponnese. It caused the death of 2 people and the injury of 8 others. Based on preliminary data provided by GCMT, INGV, USGS, IPGP and NOAGI, the epicenter is located in the western offshore area of Lefkas, while according to UPSL, AUTH and GFZ the epicenter is located in the western onshore part of Lefkas. Based on preliminary data provided by national and international seismological institutes (GCMT, USGS, INGV, UPSL, AUTH, GFZ, NOAGI, IPGP) the main shock is consistently located at depths of 7-15 km and the fault plane solutions demonstrate a NNE-SSW striking dextral strike-slip seismic fault with a reverse component that dips east at a high angle (Fig. 1). The main shock has been followed by a magnitude 5.1 earthquake at 08:33:40.8 UTC (10:33 local time) with its focus located at $38.65^{\circ} \mathrm{N}, 20.56^{\circ} \mathrm{E}$ at depth of $9 \mathrm{~km}$ (NOAGI). Western Lefkas suffered the most damage induced by the earthquake in the natural environment, the building stock and infrastructure. The earthquake environmental effects and building damage were mapped during our field reconnaissance in Lefkas Island immediately after the earthquake and are presented here.

\section{Geodynamic setting}

The island of Lefkas is located in the central part of the Ionian Sea (western Greece) (Fig. 1a) which is one of the most seismically active parts in the Mediterranean region (Makropoulos and Burton, 1984) with high seismicity rate and earthquake magnitudes up to 7.4 (Papazachos, 1990; Louvari et al., 1999). Thus, Lefkas belongs to the third zone (zone III) in the Seismic Hazard Map of Greece (EPPO, 2003) with a design ground acceleration of $0.36 \mathrm{~g}$, which is the highest for Greece. The primary tectonic structure affecting the area is the Cephalonia Transform Fault Zone (CTFZ in Fig. 1). Seismological data indicate dextral strike-slip focal mechanisms (Scordilis et al., 1985; Anderson and Jackson, 1987; Jackson and McKenzie, 1988; Papadimitriou, 1993; Papazachos and Kiratzi, 1996), which is in agreement with geodetic GPS data revealing dextral strike-slip motion of 3 cm/year (Cocard et al., 1999; Jenny et al., 2004). The CTFZ is composed of two segments; the Lefkas segment (LS in Fig. 1b) to the north located west of Lefkas Island and the Cephalonia segment (CS in Fig. 1b) to the south located west of Cephalonia Island (Scordilis et al., 1985; Kiratzi and Langston, 1991; Louvari et al., 1999). The LS extends with a length of about $40 \mathrm{~km}$ from the northwestern offshore part of Lefkas to the northern offshore part of Cephalonia Island (Fig. 1b). It strikes in a NE-SW direction (Fig. 1b), dips to the ESE and is characterized by a dextral strike-slip motion combined with a small thrust component involved in the movement. The CS occurs with a length of about $90 \mathrm{~km}$ close to the western offshore part of Cephalonia. The CTFZ plays a key role in the region's geodynamic complexity (Sorel, 1976; Mercier et al., 1987; Taymaz et al., 1991; Le Pichon et al., 1995; Papazachos and Kiratzi, 1996; Louvari et al., 1999) The CTFZ connects the subduction boundary to the south to the continental collision between the Apulian microplate and the Hellenic foreland to the north. It also separates the slowly northward and northwestward moving $(5 \mathrm{~mm} /$ year with respect to Eurasia) northern Ionian Islands from the rapidly southwestward moving 
(6-30 mm/year) central Ionian Islands (Anzidei et al., 1996; Hollenstein et al. 2006, 2008) and, therefore, represents a major boundary of the kinematic field in Greece.
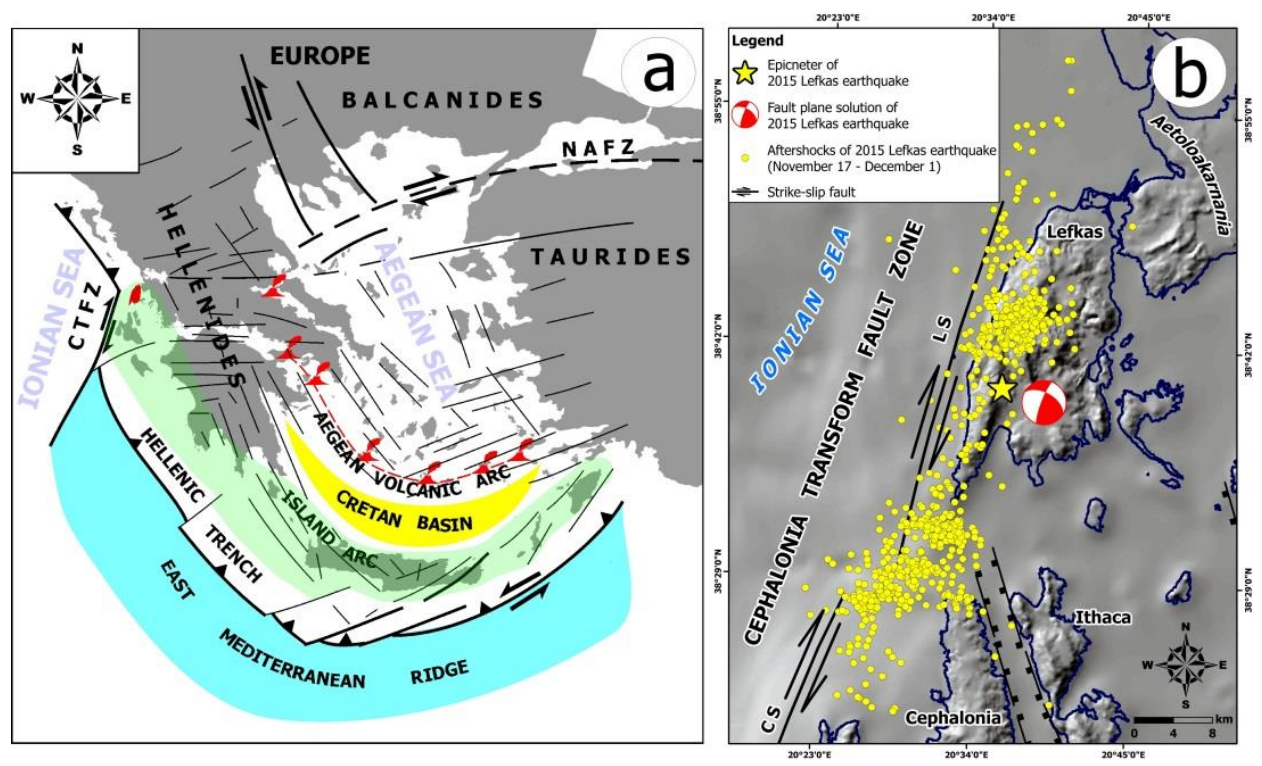

Figure 1 - (a) Structural sketch of the Hellenic Arc showing the location of Lefkas Island at the northwesternmost part of the Hellenic Arc [after Mariolakos and Papanikolaou (1981, 1987), modified], (b) The epicenter of the 2015 Lefkas earthquake, its fault plane solution and its aftershocks sequence from November 17 to December 12015 based on earthquake catalogues provided by AUTH (2015). Two distinct clusters are clearly defined by the aftershocks distribution: the northern cluster located in a distance of about $5 \mathrm{~km}$ from the epicenter of the main shock and the southern located in a distance of about $15 \mathrm{~km}$ southwest of the epicenter of the main shock.

Lefkas comprises (a) alpine formations that belong to Ionian and Paxoi (Pre-Apulian) geotectonic units, (b) molassic formations and (c) recent deposits that lie unconformably on the previous formations (Renz, 1955; Bornovas, 1964; BP, 1971; Lekkas et al., 1999, 2001; Rondoyanni 1997; Triantafyllou, 2010; Rondoyanni et al., 2012) (Fig. 2a). The largest part of Lefkas belongs to the Ionian unit, while only the southwestern part of the island and more specifically Lefkata peninsula comprises Paxoi formations (Fig. 2a). Ionian unit is composed of the Triassic evaporites, the Upper Triassic - Upper Cretaceous carbonate sequence and the Oligocene - Lower Miocene flysch sediments (Bornovas, 1964; IGRS-IFP, 1966). The Ionian unit is considered to be the paraautochthonous unit of Lefkas. Its western boundary is the west-directed Ionian overthrust onto Paxoi unit (Aubouin, 1959; Jacobshagen, 1986) (Fig. 2a). Paxoi unit is the most external unit of the Hellenides originated from the western external part of the huge External Carbonate Platform of the Hellenides (Papanikolaou et al., 2004). From the stratigraphic point of view, Paxoi unit constitutes a neritic carbonate platform from Jurassic to Miocene (Bornovas, 1964; BP, 1971; Rondoyanni, 1997; Lekkas et al., 1999, 2001). Marly formations and turbiditic limestones were formed during Early Miocene (Aquitanian). Moreover, clays and marls were deposited in Burdigalian and in Middle Miocene and it is therefore generally accepted that Paxoi unit lacks the typical flysch sedimentation of the other geotectonic units of the H1 terrane. Paxoi formations are observed in the central- and south-western part of Lefkas and extends eastwards under the Ionian formations (BP Co, 1971) (Fig. 2a). The molassic formations of Lefkas comprise mostly marine AquitanianTortonian (Bornovas, 1964; Lekkas et al., 2001) marls, bioclastic limestones, conglomerates and sandstones that are unconformably overlying the deformed Ionian formations and few outcrops of Ionian flysch turbidites (Cushing, 1985; Rondoyanni, 1997; Triantafyllou, 2010). Molassic 
formations can be seen in northeastern Lefkas, especially in the areas of Karya, Lazarata and Katouna villages, in the area north of Nydri and in southern Lefkas in a narrow elongated zone between Vassiliki and Nydri villages (Fig. 2a). Smaller outcrops are observed in the central part of Lefkas (Fig. 2a). The transgressive formations of this sequence observed northeast of Vassiliki village have been affected by the tangential (horizontal) tectonic movements that took place on the island. This fact allows the consideration of the above sequence as molasse. The recent formations of Lefkas are Quaternary deposits uncomformably overlying its alpine and molassic formations. They comprise lagoonal deposits, alluvial deposits, scree, talus cones, terra rossa and coastal deposits. Extensive occurrences of recent formations are the alluvial deposits in the areas of Lefkas town, Nydri and Vassiliki villages and the lagoonal deposits in the area around Lefkas Lagoon and Vlicho Bay (Fig. 2a).

The current geodynamic setting has been established on Lefkas Island after the completion of tangential movements and prevails throughout Pliocene - Quaternary times. It is expressed by a dense net of faults crossing not only the alpine formations of the Ionian and Paxoi geotectonic units but also the unconformably overlying formations. This net of faults created a complex system of independent fault blocks which are the following:

(a) The neotectonic unit of Lefkas town (unit 1 in Fig. 2b) is a graben located in the northeastern part of the island where Lefkas town is situated. It is a wide almost flat area comprising Quaternary formations and especially alluvial deposits unconformably covering the underlying marine and lagoonal formations. It is bounded to the south by the Frini-Apolpaena fault zone (FAFZ in Fig. 2a, 2b).

(b) Tsoukalades-Katouna neotectonic unit (unit 2 in Fig. 2b) is a horst located south of the previous neotectonic unit of Lefkas town. It is composed of Ionian carbonates in its western part and molassic formations and recent deposits in its eastern part. It is bounded to the north by the Frini-Apolpaena fault zone, to the south by the Pigadisanoi-Fraxi fault zone (PFFZ in Fig. 2a, 2b) and to the west by the Tsoukalades-Agios Nikitas fault zone (TANFZ in Fig. 2a, 2b) along the western coastal margin of the unit. The Pigadisanoi-Fraxi fault zone comprises NW-SE striking faults that also suggest significant horizontal component in the movement, while the Tsoukalades-Agios Nikitas fault zone comprises N-S and NE-SW striking faults. The uplift movements of this neotectonic unit have resulted in remarkable incision in gorges of Tsoukalades area occurred in the westen part of the horst. Marine and coastal breccia and conglomerates of Upper Miocene (Bornovas, 1964) or Early Pliocene (IFP-IGEY, 1966) age occurred in the eastern part of this unit, few meters above sea level and they are indicative of these uplift movements (Lekkas et al., 1999, 2001).

(c) Agios Nikitas neotectonic unit (unit 3 in Fig. 2b) is a small horst located in the northwestern part of the island. It comprises Ionian carbonates and it is bounded to the east by the Agios Nikitas fault zone and to the west by an almost N-S striking fault zone parallel to the coast.

(d) Drymonas neotectonic unit (unit 4 in Fig. 2b) located east of Agios Nikitas neotectonic unit is composed of Ionian carbonates, cherts and schists as wells as recent deposits and especially scree along its eastern margin. It is bounded to the west by the Agios Nikitas fault zone, to the east by the $\mathrm{N}-\mathrm{S}$ striking Drymonas fault zone (DFZ in Fig. 2a, 2b) and to south by the NW-SE striking Kalamitsi-Exantheia fault zone (KEFZ in Fig. 2a, 2b).

(e) Mega Oros - Skaroi neotectonic unit (unit 5 in Fig. 2b) located east of Drymonas neotectonic unit consists of Ionian formations including the carbonate sequence, cherts and schists and the flysch sequence as well as recent deposits including alluvial deposits and terra rossa. It is bounded to the north by the NW-SE striking Pigadisanoi-Fraxi fault zone and to the south by the NE-SW striking Sivros-Nidri fault zone (SNFZ in Fig. 2a, 2b). This neotectonic unit constitutes a structurally complex macrostructure due to the fact that it is crossed by numerous mainly N-S and NE-SW striking faults resulting in smaller blocks characterized by different relative movements.

(f) Vlicho - Poros neotectonic unit (unit 6 in Fig. 2b) located in the southeastern part of the island includes Ionian carbonates and flysch, molassic formations and recent deposits including alluvial 
deposits and scree. It is bounded to the northwest by the NE-SW striking Sivros - Nidri fault zone and to the southeast by the NW-SE striking Syvota - Sivros fault zone (SSFZ in Fig. 2a, 2b). This unit can be also divided into smaller fault blocks with different relative movements, namely the Lainaki mountain and the Vlicho and Poros peninsulas (LMT, VP and PP in Fig. $2 \mathrm{~b}$ respectively).

(g) Vassiliki neotectonic unit (unit 7 in Fig. 2b) located in the southern-central part of the island is composed of Ionian carbonates and flysch, molasse and alluvial deposits. It is bounded to the northwest by the NE-SW striking Vassiliki fault zone (VAFZ in Fig. 2a, 2b) which is the southwestern prolongation of the Sivros-Nidri fault zone and to the northeast by the NW-SE striking Syvota-Sivros fault zone. This unit is also divided into smaller units like the Maradochori-Achrada unit, Sikero unit and Lipsopyrgos peninsula (MAU, SU, LP in Fig. 2a, 2b respectively).

(h) Lefkata neotectonic unit (unit 8 in Fig. 2b) located in the southwestern part of the island comprises Jurassic-Miocene limestones and Miocene marls of Paxoi unit as well as scree. It is bounded to the north by the NW-SE striking Kalamitsi-Exantheia fault zone and the Ionian overthrust onto Paxoi unit, to the east by the NE-SW striking Vassiliki fault zone and to the west by the dextral strike-slip Athani fault zone (AFZ in Fig. 2a, 2b). It also comprises smaller units such as the Dragano-Athani graben which is bounded to the west and east by NNE-SSW striking faults (Fig. 2a, 2b).

\section{Earthquake environmental effects}

\subsection{Ground cracks}

The ground cracks induced by the 2015 Lefkas earthquake are classified as secondary earthquake environmental effects induced by the ground shaking. They were mostly observed on paved asphalt roads constructed in areas comprising mainly Upper Cretaceous limestones of Paxoi unit and secondarily Miocene marls of Paxoi unit, molassic formations and Upper Triassic - Lower Jurassic limestones of Ionian unit. In general, their length ranged from 5 to $10 \mathrm{~m}$ and their width was up to 1 $\mathrm{cm}$ and they were observed close to active faults, geotechnically unstable zones and the Ionian overthrust onto Paxoi unit. They accompanied by extensive damage to road network and limited damage to adjacent structures such as retaining walls and house perimeter stone or concrete walls. They were observed at various strikes: $\mathrm{N}^{\circ} 5^{\circ} \mathrm{E}$ striking ground cracks in the western part of Tsoukalades-Katouna unit, $\mathrm{N} 35^{\circ}-60^{\circ} \mathrm{E}, \mathrm{N} 90^{\circ}-110^{\circ} \mathrm{E}$ (Fig. 3a), $\mathrm{N} 130^{\circ}-145^{\circ} \mathrm{E}$ striking ground cracks in Dragano-Athani graben, $\mathrm{N} 45^{\circ} \mathrm{E}$ in an area located northeast of Porto Katsiki beach, $\mathrm{N} 10^{\circ}-70^{\circ} \mathrm{E}$ and $\mathrm{N} 105^{\circ}-140^{\circ} \mathrm{E}$ striking ground cracks in the southern onshore tip of Athani fault, $\mathrm{N} 160^{\circ}-180^{\circ} \mathrm{E}$ striking ground cracks in an area located $2 \mathrm{~km}$ east of Dragano village, $\mathrm{N} 30^{\circ}-44^{\circ} \mathrm{E}$ and $\mathrm{N} 155^{\circ} \mathrm{E}$ striking ground cracks in Vassiliki port (Fig. 2a).

\subsection{Slope movements}

The 2015 Lefkas earthquake triggered numerous slope movements in the western part of the island and more specifically in the western part of the Tsoukalades-Katouna neotectonic unit and in the neotectonic units of Agios Nikitas, Drymonas and Lefkata peninsula (Fig. 2a). On the contrary, such phenomena did not occur in the other neotectonic units that form the northern, central and eastern part of the island (Fig. 2a). These phenomena can be classified into rockfalls and landslides. Most of them remained active for a long time after the main earthquake mainly due to the recently established instability conditions and the ongoing aftershock sequence including earthquakes with magnitude equal to or larger than 4.0 and epicenters determined close to the western part of the island (AUTH, 2015).

Slope movements mainly induced in the western part of Lefkas were mainly observed along the western coastal part of the island (Fig. 2a) which presents N-S to NNE-SSW trending linear development. This part comprises alpine formations and recent deposits (Fig. 2a). The alpine formations comprise the carbonate rocks and the atypical flysch of Paxoi unit and the carbonate rocks of Ionian unit. The recent deposits include recent coastal formations composed of sand along 
narrow beaches and scree along faults running along the coastal area extended from Tsoukalades area located northwards to Porto Katsiki located southwards (Fig. 2a, 2b).

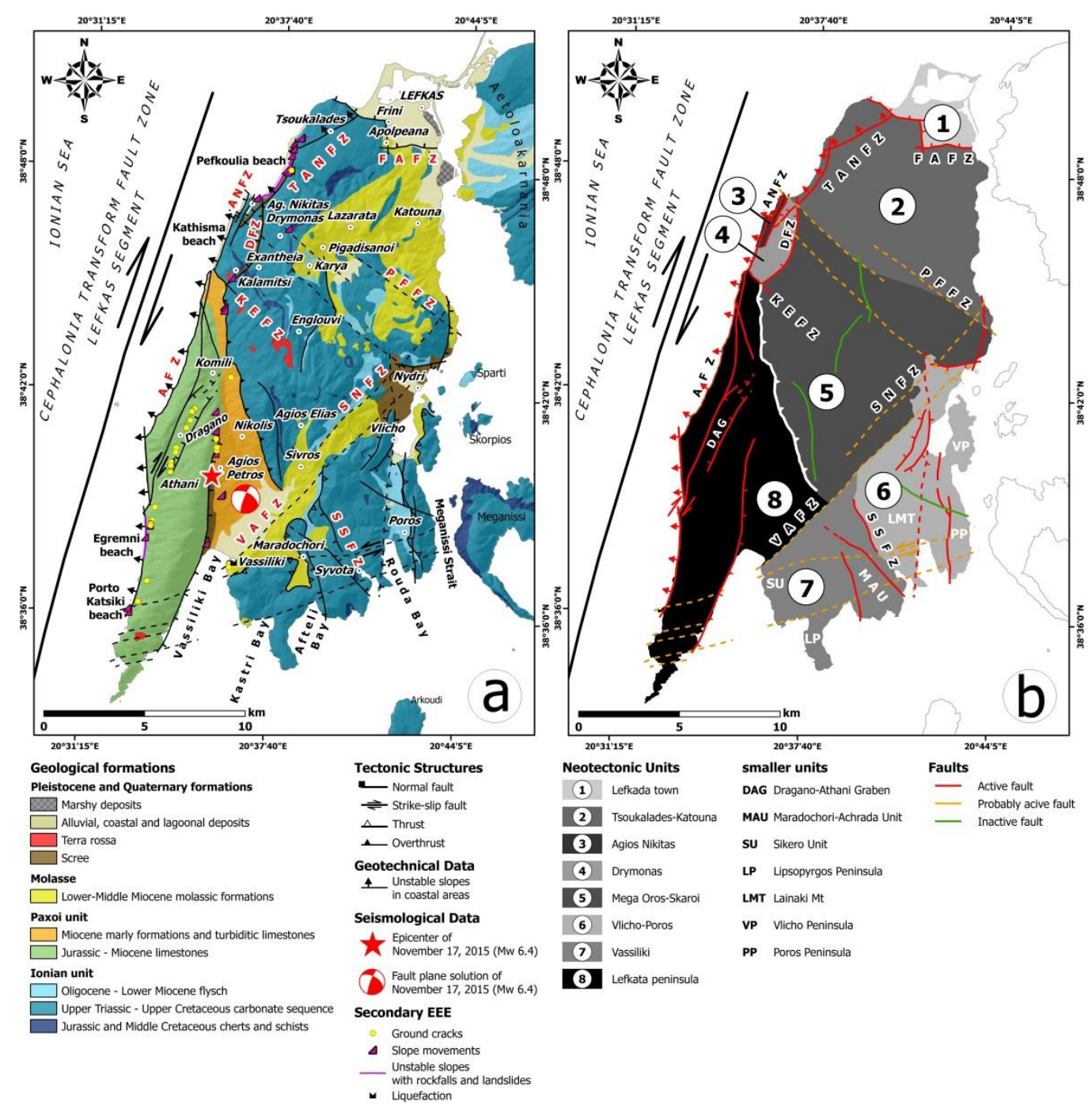

Figure 2 - (a) Neotectonic map of Lefkas Island based on Lekkas et al. (1999, 2001) and Rondoyanni et al. (2012). FAFZ: Frini-Apolpeana fault zone, TANFZ: Tsoukalades-Agios Nikitas fault zone, ANFZ: Agios Nikitas fault zone, DFZ: Drymonas fault zone, PFFZ:

Pigadisanoi-Fraxi fault zone, KEFZ: Kalamitsi-Exantheia fault zone, AFZ: Athani fault zone, SNFZ: Sivros-Nydri fault zone, VAFZ: Vassiliki fault zone, SSFZ: Syvota-Sivros fault zone, (b) The neotectonic units of Lefkas. Neotectonic faults dissected the island. They are mainly normal or strike-slip faults with a sinistral or dextral sense of shear and they are classified into active, probably active and inactive structures (Lekkas et al., 1999, 2001).

These neotectonic units are composed of smaller units.

The tectonic structure of the western coastal part of Lefkas is characterized by the presence of active faults (Cushing, 1985; Lekkas et al., 1999, 2001; Rondoyanni et al., 2012) (Fig. 2a, 2b) that play decisive role in the formation and the evolution of Lefkas. Additionally, they form a geotechnically unstable region characterized by high and steep slopes and scarps, fractured and brecciated rock mass and suitable geometry of beds and discontinuities. It is clearly evident that the tectonic activity 
in this area increased the inclination of the coastal slopes varying in height from 100 to $600 \mathrm{~m}$. The combination of (a) the endogenic processes including tectonic deformation of the crust and resulting in the lithological heterogeneity and the mechanical anisotropy of the alpine and recent formations with (b) the exogenic processes comprising repeated cycles of mechanical, chemical and organic weathering and fluvial, marine and aeolian erosion contribute to the decreased cohesion and formations loosening along the steep coastal slopes. Thus, Porto Katsiki (Fig. 3b, 3c), Ergemni, Kalamitsi, Kathisma, Agios Nikitas and Pefkoulia areas are highly susceptible to the generation of slope movements. Because of the large volume of unstable sediments created by slope movements or the probable poor dimensioning (energy, height and position) of protection barriers, anchoring and foundations, the rockfall protection works were in some places partially destroyed, while in others totally destroyed (Fig. 3d, 3e, 3f) resulting in destruction of the asphalt pavement and temporary or permanent traffic disruption.

\subsubsection{Eastern part of the neotectonic unit of Lefkata peninsula}

The eastern part of Lefkata peninsula is characterized by a fault characterized as probably active by Lekkas et al. (1999, 2001) (Fig. 2b). It juxtaposes Upper Cretaceous limestones of Paxoi unit against Miocene marls of the atypical flysch of the same unit forming extensive scree. It constitutes the main reason for the NNE-SSW trending linear development of the eastern coastline of Lefkata peninsula (Fig. 2b) and for fracturing and fragmentation of the alpine formations of Paxoi unit in this area.

Slope movements were also generated in the eastern part of neotectonic unit of Lefkata peninsula along the aforementioned probably active fault (Fig. 2a). They were classified into rockfalls and landslides. They caused partial damage to the road network including cracks and craters in the pavement and deformation of road protection barriers as boulders bounced along the street as well as traffic disruption. Unfortunately, rockfalls generated in Ponti village caused the loss of an adult woman when loose limestone blocks were detached from the adjacent steep limestone slopes and went through the infill walls of her home.

\subsubsection{Central-western part of Lefkas}

The central-western part of Lefkas is dominated by the presence of the Ionian overthrust onto Paxoi unit (Fig. 3g). This tectonic structure creates rugged morphology with steep slopes, a dense net of discontinuities and sectors of decreased cohesion and formations loosening immediately in front of the overthrust (Fig. 3g). All these aggravating factors made the area along the front of the Ionian overthrust onto Paxoi unit highly susceptible to the generation of slope movements. Thus, slope movements including rockfalls and landslides were triggered by the 2015 Lefkas earthquake (Fig. 2a).

\subsubsection{Dragano-Athani neotectonic graben}

Dragano-Athani graben is a relatively small neotectonic unit inside the major neotectonic unit of Lefkata peninsula. It is bounded to the west and east by NNE-SSW striking faults cutting Upper Cretaceous limestones of Paxoi unit. More specifically, the Dragano-Athani graben is located east of the dextral strike-slip Athani fault, which has impressive similarity of geometric and kinematic characteristics with those of the Lefkas segment of the CTFZ (Rondoyanni et al. 2012). The Upper Cretaceous limestones of Paxoi unit are highly tectonized by the abovementioned active structures resulting in their disintegration into small fragments or their decomposition into powder. Under these geological and geotechnical conditions and the resulting high susceptibility to slope movements, landslides occurred in the area north of Athani village during the 2015 Lefkas earthquake (Fig. 2a).

\subsection{Near-surface liquefaction phenomena}

Large damage was induced by the earthquake in Vassiliki port located in the southwestern part of the island (Fig. 2a) and comprised displacements and rotations of the quay seawalls, extensive longitudinal cracking of pavements and sidewalks behind seawalls and subsidence near the waterfront (Fig. 3h, 3i 3j). These phenomena are considered as evidence of near-surface liquefaction in the area of Vassiliki port. However, common manifestation of liquefaction induced by previous 
earthquakes in Vassiliki port, such as sand boils and ground fissures with ejection of muddy water (Margaris et al., 2003; Papathanassiou et al., 2005), were not observed.
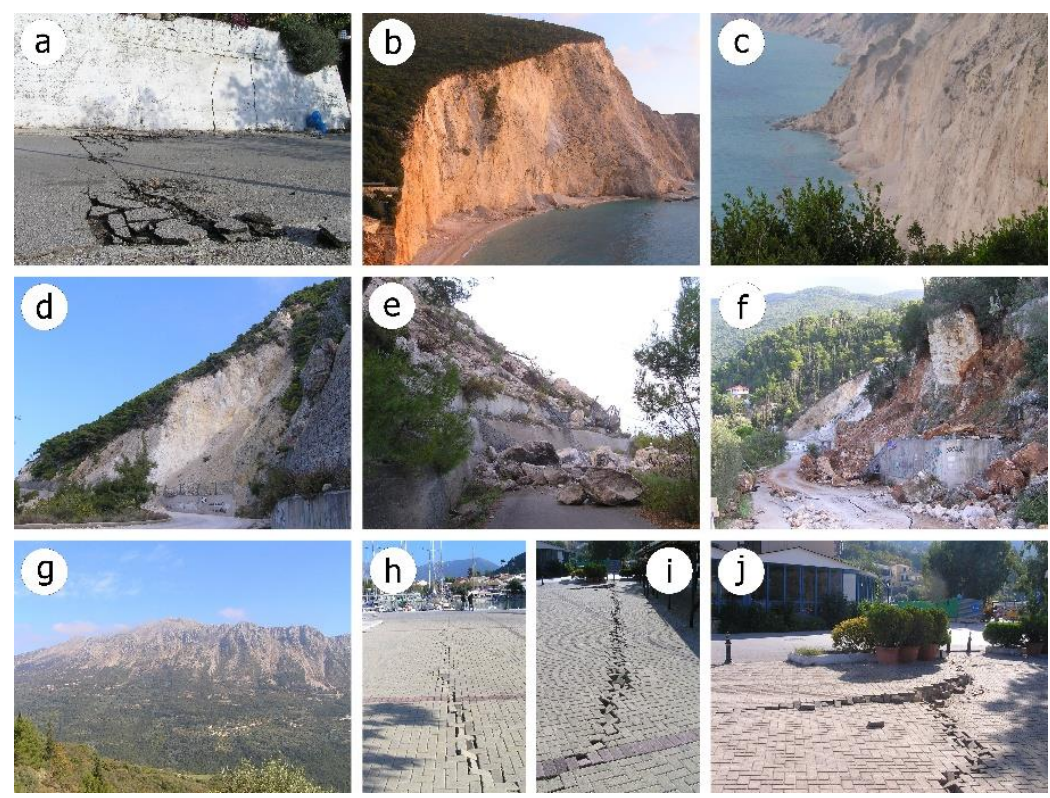

Figure 3 - Secondary effects induced by the 2015 Lefkas earthquake: (a) $\mathrm{N}_{110}^{\circ} \mathrm{E}$ striking ground cracks in Athani village causing damage to a perimeter stone retaining wall. Slope movements $(b, c)$ in Porto Katsiki coastal area, $(d, e, f)$ along the road from Tsoukalades to

Agios Nikitas and (g) along the Ionian overthrust onto Paxoi unit. (h, i) Extensive longitudinal cracking of pavements and sidewalks behind seawalls and (j) subsidence near the waterfront in Vassiliki port.

\section{Damage in building stock}

The building types in Lefkas are the following: (a) one- or two-storey stone masonry buildings, (b) one - to three-storey traditional wood buildings, (c) traditional buildings with dual structural system, (d) one- to five-storey modern reinforced concrete (R/C) buildings and (e) Middle Age and later-era buildings (Karakostas et al., 2005; Makarios and Demosthenous, 2006, 2015; Vintzileou, 2011; Vintzileou et al., 2007; Kouris and Kappos, 2015).

The 2015 Lefkas earthquake was localized in the neotectonic structure of Lefkata peninsula in the southwestern part of Lefkas Island in general and villages located in Dragano-Athani neotectonic unit in particular. Athani, Dragano and Komili villages suffered most damage to their building stock and road, power and water supply infrastructures. Less damage was observed in the other villages of Lefkata peninsula (e.g. Agios Petros, Nikolis).

All buildings constructed after the issue and the implementation of the first Greek seismic code of 1959 showed good performance during the 2015 Lefkas earthquake since none of them collapsed. $\mathrm{R} / \mathrm{C}$ buildings were affected not so much by the earthquake itself but by the generation of secondary effects. In Ponti village located west of Vassiliki bay, a boulder detached from the adjacent steep limestone slopes rolled down toward village and went through the infill walls of an R/C building (Fig. 4a). In Agios Nikitas village located in the northwestern coastal part of Lefkas, an R/C building was found on the edge of a slope and at risk of collapse (Fig. 4b).

On the contrary, severe damage was observed generally in buildings constructed without any seismic provisions before 1959 and especially in stone masonry buildings. These buildings suffered damage ranging from large and extensive cracking in most load-bearing walls, detachment of roof tiles and 
plasters from the stone masonry walls (Fig. 4c), serious failure of walls and partial structural failure of roofs and floors to total collapse of the building (Fig. 4d). Total collapses were observed in Athani and Dragano villages located in Dragano-Athani neotectonic graben.
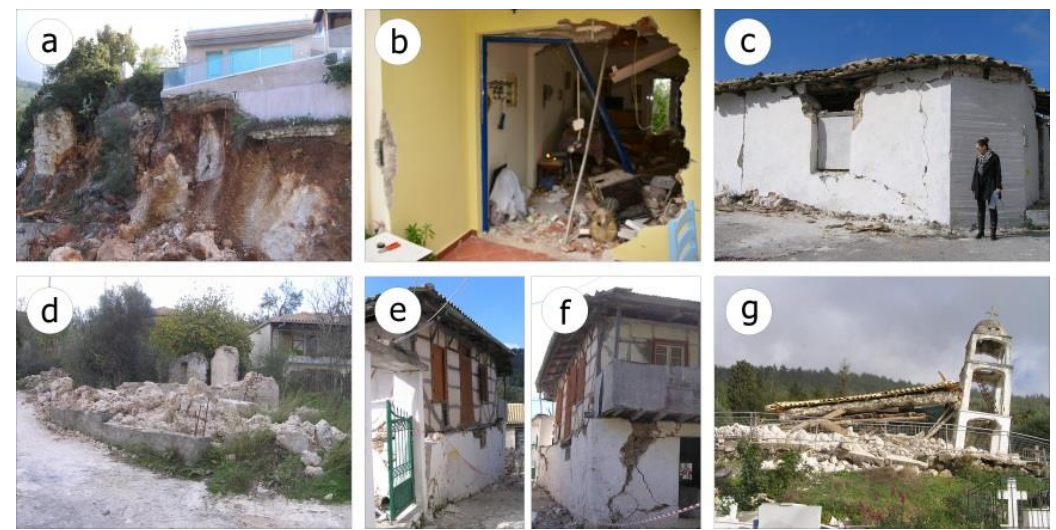

Figure 4 - (a, b) R/C buildings were affected not so much by the earthquake itself but by the generation of secondary effects. Stone masonry buildings with damage ranging from (c) cracking in the load-bearing wall to (d) total collapse of the structure. (e, f)Traditional building with dual structural system suffered partial collapse of masonry walls of the primary structural system of the ground floor, while the wooden frame of the secondary structural system successfully sustained vertical loads of the upper floor. (g) Total collapse of a church in Athani village.

It is significant to note that the traditional buildings with dual structural system performed well during this earthquake too. Some structures that are still in use in the earthquake affected area and in particular in Athani and Dragano villages suffered partial collapse of the stone masonry walls of the primary load-carrying system of the ground floor, while the wooden frame of the secondary load-carrying system successfully sustained vertical loads of the upper floor and thus the structures did not collapse (Fig. 4e, 4f). As far as the monumental buildings are concerned, churches suffered severe damage like extensive cracking of masonry load-bearing walls and partial or total collapse (Fig. 4g).

\section{Conclusions}

The seismic activity in the region was essentially expected in medium-term time scale after the 2003 earthquake in the northwestern part of Lefkas Island and the early 2014 earthquakes in the western part of Cephalonia Island. Between these earthquake affected areas, the tectonic stresses were not released for a long time after the 1948 Lefkas earthquake sequence. Instead, they were intensifying and accumulating each day until the generation of the 2015 Lefkas earthquake sequence.

The 2015 Lefkas earthquake produced earthquake environmental effects in western Lefkas. These effects were classified as ground cracks, slope movements (rockfalls and landslides) and liquefaction phenomena. The observed ground cracks were of secondary origin and provoked by the ground shaking. The slope movements induced by the 2015 Lefkas earthquake were generated in geotechnically unstable zones (a) along the steep coastal slopes of the western part of the island, (b) along the steep slopes of the eastern part of Lefkata peninsula and (c) along the Ionian overthrust onto Paxoi formations. These geotechnically unstable zones are defined by the presence of active and inactive tectonic structures resulting in highly tectonized, disintegrated and almost powdered geological formations with suitable geometry of beds and discontinuities and steep slopes intensifying substantially the instability conditions of the area and increasing the susceptibility to slope movements. Liquefaction phenomena in the strict use of the term comprising the most common and typical manifestation (sand boils and ejection of sand/water mixture) were not induced by the 2015 Lefkas 
earthquake. However, ground cracking and subsidence observed in coastal areas and port facilities of the southern part of Lefkas are attributed to near-surface liquefaction phenomena.

From the buildings damage distribution induced by the 2015 Lefkas earthquake, it is clearly shown that damage was limited to buildings of Athani, Dragano and Komili villages located in the neotectonic unit of Lefkata peninsula. Among structures designed and constructed with no seismic provisions, the stone masonry buildings and monumental structures suffered most damage, while the traditional buildings with dual structural system performed relatively well and suffered minor damage.

It is once again concluded that the western Lefkas is among the most susceptible areas to secondary earthquake-induced effects on the natural environment and damage to building stock. Similar distribution of secondary effects were also reported and recorded after previous historical and recent earthquakes in Lefkas area. More specifically, the western part of Lefkas including Agios Nikitas, Dragano and Athani areas has also suffered secondary EEE comprising subsidence during 1704, 1914, 1948 and 2003 events, slope movements mainly landslides and rockfalls during 1783, 1885, 1914, 1948 and 2003 events, ground cracking small in size and of secondary origin during 1704, 1914, 1948 and 2003 and small-scale tsunamis during 1914 and 1948 events (Margaris et al., 2003; Lekkas et al., 2004; Papathanassiou et al., 2007; Rondoyanni et al., 2012).

\section{References}

Anderson, H. and Jackson, J., 1987. Active tectonics of the Adriatic region, Geophys. J. R. Astron. Soc., 91, 937-983.

Anzidei, M., Baldi, P., Casula, G., Crespi, M. and Riguzzi, F., 1996. Repeated GPS surveys across the Ionian Sea: evidence of crustal deformations, Geophys. J. Int., 127, 257-267.

Aristotle University of Thessaloniki (AUTH), 2015. Permanent Regional Seismological Network operated by the Aristotle University of Thessaloniki, doi: 10.7914/SN/HT.

Aubouin, J., 1959. Contribution a l'étude géologique de la Grèce septentrional: le confins de l' Epire et de la Thessalie, Annales Geologiques des Pays Helleniques, 10, 1-483.

Bornovas, J., 1964. Géologie de l' île de Lefkade, Geological. and Geophysics Research (I.G.S.R.), 10(1), $142 \mathrm{pp}$.

BP Co, 1971. The geological results of petroleum exploration in western Greece, Institute of Geology Subsurface Research, Athens, 10, 73 pp.

Cocard, M., Kahle, H.-G., Peter, Y., Geiger, A., Veis, G., Felekis, S., Billiris, H. and Paradissis, D., 1999. New constraints on the rapid crustal motion of the Aegean region: recent results inferred from GPS measurements (1993-1998) across the West Hellenic Arc, Greece, Earth Planet. Sci. Lett., 172, 39-47.

Cushing, M., 1985. Evolution structurale de la marge nord-ouest hellénique dans l'île de Lefkas et ses environs (Grèce nord-occidentale), Ph.D. Thesis, Univ. d' Orsay.

Hollenstein, C.H., Geiger, A., Kahle, H.G. and Veis, G., 2006. CGPS time-series and trajectories of crustal motion along the West Hellenic Arc, Geophys. J. Int., 164(1), 182-191.

Hollenstein, C.H., Müller, M.D., Geiger, A. and Kahle, H.-G., 2008. Crustal motion and deformation in Greece from a decade of GPS measurements 1993-2003, Tectonophysics, 449, 17-40.

IGRS-IFP, 1966. Etude geologique de l'Epire, Technip, 306 pp., Paris.

Jackson, J.A. and McKenzie, D.P., 1988. The relationship between plate motions and seismic moment tensors, and the rates of active deformation in the Mediterranean and Middle East, Geophys. J. R. Astron. Soc., 93, 45-73.

Jacobshagen, V., 1986. Geologie von Griechenland. Berlin: Gebruder Bornträger, 363 pp.

Jenny, S., Goes, S., Giardini, D. and Kahle, H.-G., 2004. Earthquake recurrence parameters from seismic and geodetic strain rates in the eastern Mediterranean, Geophys. J. Int., 157, 1331-1347.

Karakostas, C., Lekidis, V., Makarios, T., Salonikios, T., Sous, I. and Demosthenous, M., 2005. Seismic response of structures and infrastructure facilities during the Lefkas, Greece earthquake of 14/8/2003, Engineering Structures, 27, 213-227. 
Kiratzi, A. and Langston, C., 1991. Moment tensor inversion of the January 17, 1983 Kefallinia event of Ionian Islands (Greece), Geophys. J. Int., 105, 529-535.

Kouris, L.A.S. and Kappos A.J., 2015. Fragility Curves and Loss Estimation for Traditional TimberFramed Masonry Buildings in Lefkas, Greece. In: Psycharis, I.N. et al. (eds.), Seismic Assessment, Behavior and Retrofit of Heritage Buildings and Monuments, Computational Methods in Applied Sciences, 12, 199-233, doi: 10.1007/978-3-319-16130-3_8.

Le Pichon, X., Chamot-Rooke, N. and Lallemant, S., 1995. Geodetic determination of the kinematics of central Greece with respect to Europe: implications for eastern Mediterranean tectonics, Journal of Geophysical Research, 100(B7), 12675-12690.

Lekkas, E., Danamos, G. and Lozios, S., 1999. Analytical study of seismicity, seismic hazard and geotechnical conditions of Lefkada with emphasis in the area of the town and the west coast. Applied Scientific Research Programm, Department of Dynamic Tectonic Applied Geology, University of Athens (in Greek).

Lekkas, E., Danamos, G. and Lozios, S., 2001. Neotectonic structure and evolution of Lefkas Island, Bulletin of the Geological Society of Greece, 34(1), 157-163.

Lekkas, E., Danamos, G., Lozios, S., Skourtsos, E. and Verykiou, E., 2004. The geographic distribution of landslides of Lefkas earthquake (August 14 2003) and factors affecting their generation, 10th International Congress of the Greek Geological Society, Extended Abstracts, 130-131.

Lekkas, E.L and Mavroulis, S.D., 2015a. Earthquake environmental effects and ESI 2007 seismic intensities of the early 2014 Cephalonia (Ionian Sea, western Greece) earthquakes (January 26 and February 3, Mw 6.0), Nat Hazards, 78, 1517-1544.

Lekkas, E.L and Mavroulis, S.D., 2015b. Fault zones ruptured during the early 2014 Cephalonia Island (Ionian Sea, Western Greece) earthquakes (January 26 and February 3, Mw 6.0) based on the associated co-seismic surface ruptures, J. Seismol., doi: 10.1007/s10950-015-9510-3.

Louvari, E., Kiratzi, A.A. and Papazachos, B.C., 1999. The Cephalonia Transform Fault and its extension to western Lefkada Island (Greece), Tectonophysics, 308, 223-236.

Makarios, T. and Demosthenous, M., 2006. Seismic response of traditional buildings of Lefkas Island, Greece, Engineering Structures, 28, 264-278.

Makarios, T. and Demosthenous, M., 2015. Earthquake Response of Historic Buildings at Lefkas Island. In: Ruggieri, N. et al., eds., Historical Earthquake-Resistant Timber Frames in the Mediterranean Area, 149-156, DOI 10.1007/978-3-319-16187-7_12.

Makropoulos, K.C. and Burton, P.W., 1984. Greek tectonics and seismicity, Tectonophysics, 106, 275-304.

Margaris, B., Papaioannou, C., Theodulidis, N., Savvaidis, A., Anastasiadis, A., Klimis, N., Makra, K., Demosthenous, M., Karakostas, C., Lekidis, V., Makarios, T., Salonikios, T., Sous, I., Carydis, P., Lekkas, E., Lozios, S., Skourtsos, E. and Damanos, G., 2003. Preliminary observations on the August 14, 2003, Lefkada Island (Western Greece) Earthquake, EERI, Special Earthquake Report, Nov. 2003.

Mariolakos, I. and Papanikolaou, D., 1981. The neogene basins of the Aegean Arc from the paleogeographic and the geodynamic point of view, In: Proceedings of the International Symposium Hellenic Arc and Trench (HEAT), I, 383-399.

Mariolakos, I. and Papanikolaou, D., 1987. Deformation pattern and relation between deformation and seismicity in the Hellenic arc, Bull Geol Soc Greece, XIX, 59-76.

Mercier, J., Sorel, D. and Simeakis, K., 1987. Changes in the state of stress in the overriding plate of a subduction zone: the Aegean Arc from the Pliocene to the Present, Ann. Tectonicae, 1(1), 20-39.

Papadimitriou, E.E., 1993. Focal mechanism along the convex side of the Hellenic Arc, Boll. Geof. Teor. Appl., 35, 140, 401-426.

Papanikolaou, D., Bargathi, H., Dabovski, C., Dimitriu, R., El-Hawat, A., Ioane, D., Kranis, H., Obeidi, A., Oaie, G., Seghedi, A. and Zagorchev, I., 2004. Transect VII: East European Craton Scythian Platform - Dobrogea - Balkanides - Rhodope Massif - Hellenides - East Mediterranean - Cyrenaica. In: The TRANSMED Atlas - The Mediterranean Region from Crust to Mantle Geological and Geophysical Framework of the Mediterranean and the Surrounding Areas, Editors: Cavazza, W., Roure, F., Spakman, W., Stampfli, G.M., Ziegler, P.A. 
Papathanassiou, G. and Pavlides, S., 2007. Using the INQUA scale for the assessment of intensity: Case study of the 2003 Lefkada (Ionian Islands), Greece earthquake, Quaternary International, 173-174, 4-14.

Papathanassiou, G., Pavlides, S. and Ganas, A., 2005. The 2003 Lefkada earthquake: Field observations and preliminary microzonation map based on liquefaction potential index for the town of Lefkada, Engineering Geology, 82, 12-31.

Papazachos, B.C., 1990. Seismicity of the Aegean and surrounding area, Tectonophysics, 178, 287-308.

Papazachos, C. and Kiratzi, A., 1996. A detailed study of the active crustal deformation in the Aegean and surrounding area, Tectonophysics, 253, 129-153.

Renz, C., 1955. Die vorneogene Stratigraphie der normal-sedimentaren Formationen Griechenlands, Institute for Geology and Subsurface Research, $637 \mathrm{pp}$.

Rondoyanni, T., 1997. Les seismes et l'environnement geólogique de l'île de Lefkade, Grèce: Passe et Futur, In: Marinos, Koukis, Tsiambaos and Stournaras, eds., Engineering Geology and the Environment, International Symposium on Engineering Geology and the Environment. A.A. Balkema, Rotterdam, 1469-1474.

Rondoyanni, Th., Sakellariou, M. and Baskoutas, J., Christodoulou, N., 2012. Evaluation of active faulting and earthquake secondary effects in Lefkas Island, Ionian Sea, Greece: an overview, Natural Hazards, 61, 843-860, doi: 10.1007/s11069-011-0080-6.

Scordilis, E.M., Karakaisis, G.F., Karakostas, B.G., Panagiotopoulos, D.G., Comninakis, P.E. and Papazachos, B.C., 1985. Evidence for transform faulting in the Ionian sea: The Cephalonia island earthquake sequence of 1983, Pure Appl. Geophys., 123(3), 388-397, doi: 10.1007/BF00880738.

Sorel, D., 1976. Etude neotectonique des isles ioniennes de Cephalonie et Zanthe et de l' Elide occidentale (Grece), These du 3em cycle, Universite de Paris-Sud, Centre d' Orsay.

Taymaz, T., Jackson, J. and McKenzie, D., 1991. Active tectonics of the north and central Aegean Sea, Geophys. J. Int., 106, 433-490.

Triantafyllou, M., 2010. Calcareous nannofossil biostratigraphy of Langhian deposits in Lefkas (Ionian Islands), Bulletin of the Geological Society of Greece, XLIII/2, 754-762.

Vintzileou, E., 2011. Timber-reinforced structures in Greece: 2500 BC-1900 AD, Structures and Buildings, 164, SB3, 167-180, doi: 10.1680/stbu.9.00085

Vintzileou, E., Zagkotsis, A., Repapis, C. and Zeris, Ch., 2007. Seismic behaviour of the historical structural system of the island of Lefkas, Greece, Construction and Building Materials, 21, $225-236$. 